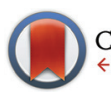

CrossMark \&lick for updates

Cite this: Dalton Trans., 2016, 45 1007

Received 28th September 2015, Accepted 23rd November 2015 DOI: $10.1039 / \mathrm{c} 5 \mathrm{dt} 03786 \mathrm{~g}$ www.rsc.org/dalton

\title{
Crystal structure evolution and luminescence properties of color tunable solid solution phosphors $\mathrm{Ca}_{2+x} \mathrm{La}_{8-x}\left(\mathrm{SiO}_{4}\right)_{6-x}\left(\mathrm{PO}_{4}\right)_{x} \mathrm{O}_{2}: \mathrm{Eu}^{2+}$
}

\author{
Yufei Xia, ${ }^{a}$ Jian Chen, ${ }^{a}$ Yan-gai Liu, ${ }^{\star a}$ Maxim S. Molokeev, ${ }^{\text {b,c }}$ Ming Guan, ${ }^{a}$ \\ Zhaohui Huang a and Minghao Fang ${ }^{a}$
}

\begin{abstract}
A series of apatite solid solution phosphors $\mathrm{Ca}_{2+x} \mathrm{La}_{8-x}\left(\mathrm{SiO}_{4}\right)_{6-x}\left(\mathrm{PO}_{4}\right)_{x} \mathrm{O}_{2}: \mathrm{Eu}^{2+}(x=0,2,4,6)$ were synthesized by a conventional high-temperature solid-state reaction. The phase purity was examined using XRD, XPS and XRF. The crystal structure information, such as the concentration, cell parameters and occupation rate, was analyzed using a Rietveld refinement, demonstrating that the $\mathrm{Eu}^{2+}$ activated the $\mathrm{Ca}_{2} \mathrm{La}_{8}\left(\mathrm{SiO}_{4}\right)_{6} \mathrm{O}_{2}$ and $\mathrm{Ca}_{8} \mathrm{La}_{2}\left(\mathrm{PO}_{4}\right)_{6} \mathrm{O}_{2}$ to form continuous solid solution phosphors. Different behaviors of luminescence evolution in response to structural variation were verified among the series of phosphors. Two kinds of $\mathrm{Eu}^{2+}$ ion sites were proved using low temperature PL spectra (8k) and room temperature decay curves. The substitution of large $\mathrm{La}^{3+}$ ions by small $\mathrm{Ca}^{2+}$ ions induced a decreased crystal field splitting of the $\mathrm{Eu}^{2+}$ ions, which caused an increase in emission energy from the $5 \mathrm{~d}$ excited state to the $4 \mathrm{f}$ ground state and a resultant blue-shift from $508 \mathrm{~nm}$ to $460 \mathrm{~nm}$. Therefore, with the crystal structure evolution, the emitted color of the series of phosphors could be tuned from green to blue by adjusting the ratio of $\mathrm{Ca} / \mathrm{La}$.
\end{abstract}

\section{Introduction}

Compared to conventional incandescent or fluorescent lamps, LED-based lighting devices fabricated by coating the yellowemitting phosphor YAG: $\mathrm{Ce}^{3+}$ on blue InGaN LED chips have incited a revolution in the lamp industry due to their many advantages, such as significant power reduction, longer lifetime, higher luminous efficiency, environmental friendliness and brightness. ${ }^{1-3}$ However, this combination exhibits a poor color rendering index $(\mathrm{CRI} \approx 70-80)$ and a high correlated color temperature (CCT $\approx 7750 \mathrm{~K}$ ) attributed to the insufficient red emission. ${ }^{4,5}$ One solution is to assemble LEDs by pumping a near-ultraviolet (n-UV) emitting chip with a mixture of blue, green and red emitting phosphors, which can then emit high quality white light with a smoother spectral distribution over the whole visible range. ${ }^{6,7}$

The crystal field strength and coordination environment have great influences on the outermost electron transition of

\footnotetext{
${ }^{a}$ School of Materials Science and Technology, Beijing Key Laboratory of Materials Utilization of Nonmetallic Minerals and Solid Wastes, National Laboratory of Mineral Materials, China University of Geosciences, Beijing, 100083, China. E-mail: liuyang@cugb.edu.cn

${ }^{b}$ Laboratory of Crystal Physics, Kirensky Institute of Physics, SB RAS, Krasnoyarsk 660036, Russia

${ }^{c}$ Department of Physics, Far Eastern State Transport University, Khabarovsk 680021, Russia
}

the $\mathrm{Eu}^{2+}$ ion, the most frequently used activator in phosphors, because the active electronic level is not shielded against the surrounding ligands, ${ }^{8-10}$ indicating that $\mathrm{Eu}^{2+}$ ions can emit light from the ultraviolet to the infrared with broadband emitting fluorescence. ${ }^{11,12}$ It is well known that apatite structure compounds (space group $P 6_{3} / \mathrm{m}$ ), with a general chemical formula of the form $\mathrm{A}_{10}\left(\mathrm{XO}_{4}\right)_{6} \mathrm{Z}_{2}\left(\mathrm{~A}=\mathrm{Ca}^{2+}, \mathrm{Ba}^{2+}, \mathrm{Ce}^{3+}, \mathrm{La}^{3+}, \mathrm{Y}^{3+}\right.$, etc., $\mathrm{X}=\mathrm{P}^{5+}, \mathrm{As}^{5+}, \mathrm{Si}^{4+}$, etc., and $\mathrm{Z}=\mathrm{O}^{2-}, \mathrm{F}^{-}, \mathrm{Cl}^{-}, \mathrm{OH}^{-}$, etc. $){ }^{13}$ contain two kinds of cation sites: the 9-fold coordinated $4 \mathrm{f}$ sites with $C_{3}$ point symmetry and the 7-fold coordinated $6 \mathrm{~h}$ sites with a $C_{\mathrm{S}}$ point symmetry, which are suitable for the substitution of various rare-earth-metal ions. ${ }^{14-16}$ Consequently, due to their adjustable structures, and excellent thermal and physicochemical stabilities, apatite compounds have become highly efficient host materials for the luminescence of various rare earth ions and have aroused widespread attention. ${ }^{17-19}$ As discussed above, the coordination environment of the $\mathrm{Eu}^{2+}$ site is anticipated to be changed via chemical composition variation among solid solution phosphors. ${ }^{20}$ Thus, the emitted color can be controlled by doping $\mathrm{Eu}^{2+}$ ions into a series of apatite solid solution hosts which are expected to display adjustable emission spectra in a wide range to meet the requirements of multi-color phosphors.

In this study, the coordination environment variation of the $\mathrm{Eu}^{2+}$ ion has been realized by the replacement of $\mathrm{Ca}^{2+}$ ions with $\mathrm{La}^{3+}$ ions and resulted in crystal splitting decreases of the $\mathrm{Eu}^{2+}$ ion, a series of color tunable solid solution phosphors 
$\mathrm{Ca}_{2+x} \mathrm{La}_{8-x}\left(\mathrm{SiO}_{4}\right)_{6-x}\left(\mathrm{PO}_{4}\right)_{x} \mathrm{O}_{2}: \mathrm{Eu}^{2+}(x=0,2,4,6)$ were successfully prepared by a high-temperature solid-state reaction. Moreover, it's worth noting that the replacement of $\left[\mathrm{PO}_{4}\right]^{3-}$ with the $[\mathrm{SiO} 4]^{4-}$ tetrahedron was introduced into the solid solution to realize the charge compensation because of the different valences between $\mathrm{Ca}^{2+}-\mathrm{La}^{3+}$ and also that the $\mathrm{Ca}_{4} \mathrm{La}_{6}\left(\mathrm{SiO}_{4}\right)_{4}$ $\left(\mathrm{PO}_{4}\right)_{2} \mathrm{O}_{2}: \mathrm{Eu}^{2+}$ and $\mathrm{Ca}_{6} \mathrm{La}_{4}\left(\mathrm{SiO}_{4}\right)_{2}\left(\mathrm{PO}_{4}\right)_{4} \mathrm{O}_{2}: \mathrm{Eu}^{2+}$ phosphors were synthesized for the first time.

The phase purity was demonstrated by XRD, XPS and XRF, and the crystal structure information was analyzed base on Rietveld refinement results. In addition, the relationship between the crystal structure evolutions, the PLE and PL spectra at normal and low temperatures, the lifetimes and the temperature dependence spectra have been discussed in detail.

\section{Experimental}

\subsection{Materials and synthesis}

A series of apatite solid solution phosphors $\mathrm{Ca}_{2+x} \mathrm{La}_{8-x}\left(\mathrm{SiO}_{4}\right)_{6-x}\left(\mathrm{PO}_{4}\right)_{x} \mathrm{O}_{2}: 0.02 \mathrm{Eu}^{2+}(x=0,2,4,6)$ were synthesized according to a conventional high-temperature solidstate method. $\mathrm{Ca}_{2} \mathrm{CO}_{3}$ (analytical reagent (A. R.)), $\mathrm{La}_{2} \mathrm{O}_{3}$ (A. R.), $\mathrm{SiO}_{2}$ (A. R.), $\mathrm{NH}_{4} \mathrm{H}_{2} \mathrm{PO}_{4}$ (A. R.), and $\mathrm{Eu}_{2} \mathrm{O}_{3}$ (A. R.) were used as the raw materials. After the raw materials were well ground in an agate mortar for $10 \mathrm{~min}$ according to the stoichiometric amounts of reactants, all the materials were preheated for $1 \mathrm{~h}$ at $1000{ }^{\circ} \mathrm{C}$ in a corundum crucible to eliminate $\mathrm{H}_{2} \mathrm{O}$ and $\mathrm{CO}_{2}$. Then, the mixed powders were sintered at $1525^{\circ} \mathrm{C}$ in a reductive atmosphere $\left(\mathrm{H}_{2} 10 \%, \mathrm{~N}_{2} 90 \%\right)$ for $6 \mathrm{~h}$ in a horizontal tube furnace. Finally, the sintered products were well ground after cooling down to room temperature.

\subsection{Characterization}

The X-ray diffraction (XRD) data of the powder samples were collected on an X-ray powder diffractometer (D/max-IIIA, Rigaku, Japan) with a step-wise scanning mode over the
$2 \theta$ range of $10^{\circ}-110^{\circ}$ using $\mathrm{Cu} \mathrm{K \alpha}$ radiation $(1.5406 \AA)$ under an operating voltage $(40 \mathrm{kV})$ and current $(100 \mathrm{~mA})$. The XRD patterns, which were submitted for Rietveld refinement, were acquired at a step size of $0.02^{\circ}$ with a counting time of $2 \mathrm{~s}$ per step.

X-ray photoelectron spectroscopy (XPS) measurements were collected using a Kratos Axis Ultra DLD, employing an MCP stack \& delay-line photoelectron detector with scanned \& snapshot spectroscopy modes. X-ray Fluorescence (XRF) measurements were measured by utilizing a Rigaku ZSX Primus II $\mathrm{X}$-ray fluorescence spectrograph. The photoluminescence emission (PL) and the photoluminescence excitation (PLE) spectra at $298 \mathrm{k}$ and $8 \mathrm{k}$ were measured using a Hitachi F-4600 fluorescence spectrophotometer (Japan) equipped with a $150 \mathrm{~W}$ Xe lamp as the excitation source. The temperature-dependent luminescence properties were measured on the same spectrophotometer which was assembled with a computer-controlled electric furnace and a self-made heating attachment. The morphology was observed using high-resolution transmission electron microscopy (HRTEM; JEM-21000, JEOL, Japan). The roomtemperature luminescence decay curves were obtained from a spectrofluorometer (Horiba, Jobin Yvon TBXPS) using a tunable pulse laser radiation (nano-LED) for the excitation.

\section{Results and discussion}

\subsection{Phase formation and structural characteristics}

The XRD patterns of $\mathrm{Ca}_{2+x} \mathrm{La}_{8-x}\left(\mathrm{SiO}_{4}\right)_{6-x}\left(\mathrm{PO}_{4}\right)_{x} \mathrm{O}_{2}: 0.02 \mathrm{Eu}^{2+}(x=$ $0,2,4,6)$ and the standard PDF card (JCPDF 29-0337) of $\mathrm{Ca}_{2} \mathrm{La}_{8}$ $\left(\mathrm{SiO}_{4}\right)_{6} \mathrm{O}_{2}$ are displayed in Fig. 1a. All the diffraction peaks of these samples matched well with the JCPDF 29-0337 card, indicating that the series of solid solution phosphors had been prepared successfully and that the introduction of the $\mathrm{Eu}^{2+}$ ion did not cause any impurity phase. In addition, the diffraction peaks of the last three samples $(x=2,4,6)$ have obviously shifted towards the high degrees with the increase of the ratio
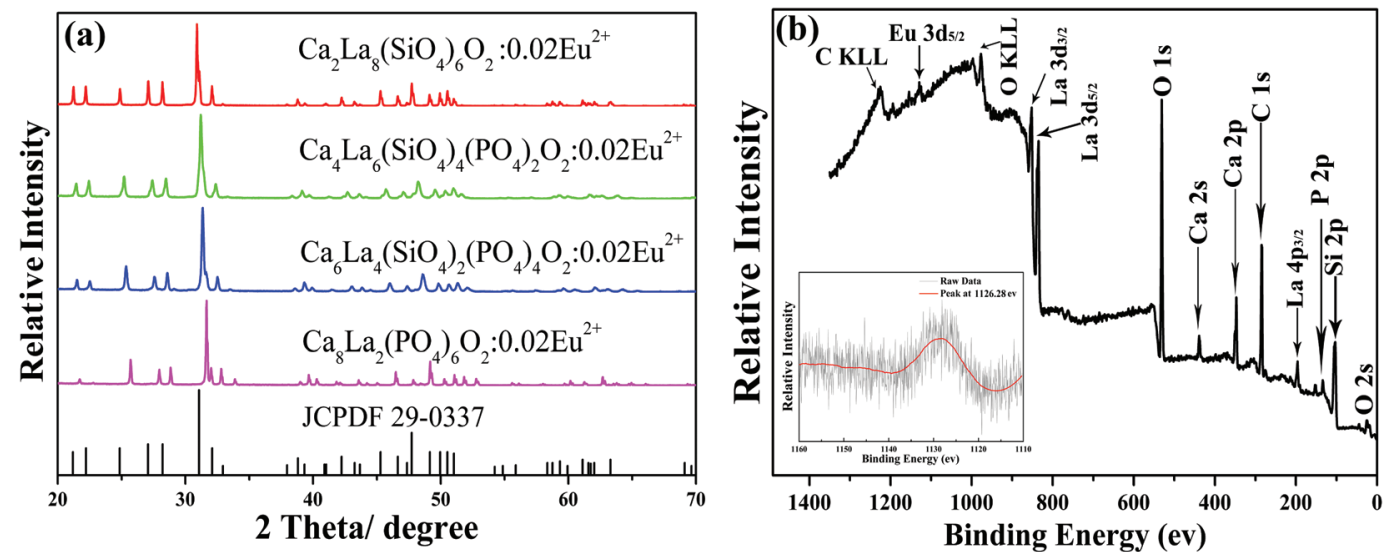

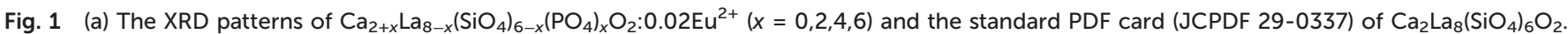
(b) The photoelectron survey spectra of the $\mathrm{Ca}_{6} \mathrm{La}_{4}\left(\mathrm{SiO}_{4}\right)_{2}\left(\mathrm{PO}_{4}\right)_{4} \mathrm{O}_{2}: 0.02 \mathrm{Eu}^{2+}$ sample. The inset shows the high-resolution XPS spectra at the Eu $3 d_{5 / 2}$ position. 
of $\mathrm{Ca} / \mathrm{La}$. This can be explained as the substitution of the large $\mathrm{La}^{3+}$ ion by the small $\mathrm{Ca}^{2+}$ ion and the large $\left[\mathrm{SiO}_{4}\right]^{4-}$ tetrahedron by the small $\left[\mathrm{PO}_{4}\right]^{3-}$ tetrahedron causes a decrease in the lattice constant of the $\mathrm{Ca}_{2+x} \mathrm{La}_{8-x}\left(\mathrm{SiO}_{4}\right)_{6-x}\left(\mathrm{PO}_{4}\right)_{x} \mathrm{O}_{2}$ hosts, ${ }^{21}$ which is also evidence demonstrating the existence of a solid solution in the whole range $(x=0,2,4,6) .{ }^{9}$ The photoelectron survey spectrum of the $\mathrm{Ca}_{6} \mathrm{La}_{4}\left(\mathrm{SiO}_{4}\right)_{2}\left(\mathrm{PO}_{4}\right)_{4} \mathrm{O}_{2}: 0.02 \mathrm{Eu}^{2+}$ sample is plotted in Fig. 1b, depicting photoelectron peaks corresponding to O $2 \mathrm{~s}, \mathrm{Si} 2 \mathrm{p}, \mathrm{P} 2 \mathrm{p}, \mathrm{La} 4 \mathrm{p}_{3 / 2}$, Ca $2 \mathrm{p}, \mathrm{Ca} 2 \mathrm{~s}, \mathrm{O} 1 \mathrm{~s}$, La $3 \mathrm{~d}_{5 / 2}$, La $3 \mathrm{~d}_{3 / 2}$ and $\mathrm{Eu} 3 \mathrm{~d}_{5 / 2}$ emission. The inset shows the high-resolution XPS spectrum at the Eu $3 d_{5 / 2}$ position, and the peak at $1126.28 \mathrm{ev}$ agrees well with the signal of $\mathrm{Eu}^{2+} 3 \mathrm{~d}_{5 / 2}$, demonstrating the existence of the $\mathrm{Eu}^{2+}$ ion. Furthermore, the elemental content of the $\mathrm{Ca}_{6} \mathrm{La}_{4}\left(\mathrm{SiO}_{4}\right)_{2}\left(\mathrm{PO}_{4}\right)_{4} \mathrm{O}_{2}: 0.02 \mathrm{Eu}^{2+}$ sample was further examined and calculated by XRF. As shown in Table 1, the proportions of all components match well with the suggested formula.

Fig. 2a displays the crystal structure of the $2 \times 2 \times 2$ unit cells of $\mathrm{Ca}_{4} \mathrm{La}_{6}\left(\mathrm{SiO}_{4}\right)_{4}\left(\mathrm{PO}_{4}\right)_{2} \mathrm{O}_{2}$, which is chosen as the representative. Obviously, $\mathrm{Ca}_{4} \mathrm{La}_{6}\left(\mathrm{SiO}_{4}\right)_{4}\left(\mathrm{PO}_{4}\right)_{2} \mathrm{O}_{2}$ has a layered structure and contains two kinds of cation sites: the inner-

Table 1 The main parameters of the XRF measurements

\begin{tabular}{lllll}
\hline Component & Result & Unit & Intensity & $\begin{array}{l}\text { Spectral lines } \\
\text { of the element }\end{array}$ \\
\hline $\mathrm{O}$ & 23.5 & Mass\% & 0.0745 & O-KA \\
$\mathrm{Si}$ & 3.17 & Mass\% & 3.064 & Si-KA \\
$\mathrm{P}$ & 8.04 & Mass\% & 20.233 & P-KA \\
$\mathrm{Ca}$ & 18.7 & Mass\% & 35.581 & Ca-KA \\
$\mathrm{La}$ & 42.5 & Mass\% & 6.245 & La-LA \\
$\mathrm{Eu}$ & 1.55 & Mass\% & 0.5759 & Eu-LA
\end{tabular}

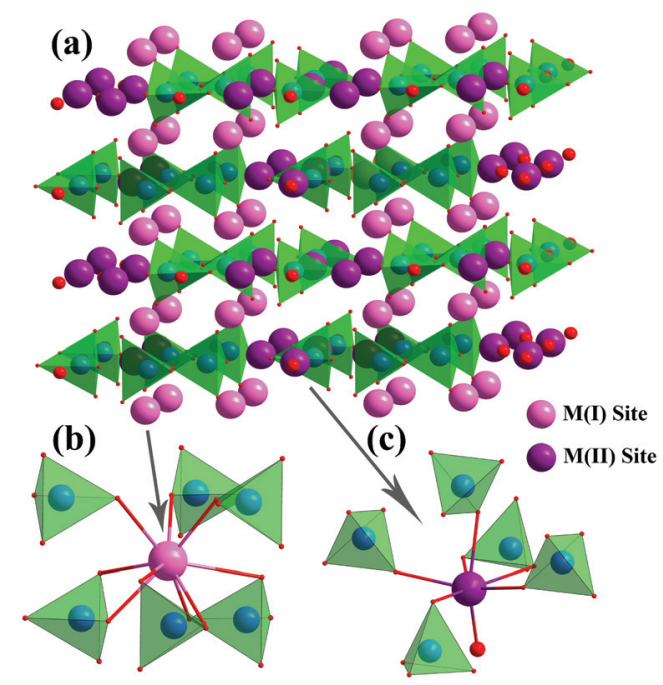

Fig. 2 (a) The crystal structure of the $2 \times 2 \times 2$ unit cells of $\mathrm{Ca}_{4} \mathrm{La}_{6}\left(\mathrm{SiO}_{4}\right)_{4}\left(\mathrm{PO}_{4}\right)_{2}: 0.02 \mathrm{Eu}^{2+}$, (b) the coordination environment of the $M(1)$ site with the local symmetry $C_{3}$ and (c) the $M($ (I) site with the local symmetry $C_{\mathrm{s}}$. laminar site labeled $\mathrm{M}(\mathrm{I})$ with the local symmetry $C_{3}$ and the inter-laminar site labeled $\mathrm{M}$ (II) with the local symmetry $C_{\mathrm{S}}{ }^{22}$ The two kinds of different coordination environment of the cation sites are displayed in Fig. $2 \mathrm{~b}$ and c. The M(I) site at the $4 \mathrm{f}$ site $\left(C_{3}\right)$ was surrounded by 9 oxygen atoms to form a monocaped square antiprism, which was connected with tetrahedral $\mathrm{PO}_{4} / \mathrm{SiO}_{4}$ groups, and the $\mathrm{M}(\mathrm{II})$ site at the $6 \mathrm{~h}$ site $\left(C_{\mathrm{S}}\right)$ formed a pentagonal bipyramid with the surrounding 7 oxygen atoms and these bipyramids were connected with each other through a vertex. Theoretically, both the $\mathrm{Ca}^{2+}$ ion and the $\mathrm{La}^{3+}$ ion are uniformly distributed in the two kinds of cationic sites, ${ }^{23}$ illustrating that the ratio of $\mathrm{Ca} / \mathrm{La}$ is easily changed by adjusting the proportion of raw materials.

The four XRD patterns were analyzed using the Rietveld refinement. The observed $(x)$, calculated (red) and difference (gray) XRD profiles for the refinements of $\mathrm{Ca}_{2+x} \mathrm{La}_{8-x}\left(\mathrm{SiO}_{4}\right)_{6-x^{-}}$ $\left(\mathrm{PO}_{4}\right)_{x} \mathrm{O}_{2}(x=0,2,4,6)$ are shown in Fig. $3 \mathrm{a}-\mathrm{d}$. The main refinement parameters of the processing and refinement results are presented in Table 2. The results of the refinement further demonstrate that the series of solid solution phosphors are single phase without any impurity or secondary phases. On the other hand, the ranges of the weighted profile $R$-factor $\left(R_{\mathrm{wp}}\right)$ and the $R$-Bragg factor $\left(R_{\mathrm{B}}\right)$ are $10.038 \%-11.012 \%$ and $1.792 \%-$ $2.777 \%$, respectively, indicating that the crystal structures of these phosphors match well with the starting model $\left(\mathrm{Ca}_{2} \mathrm{La}_{8}\left(\mathrm{SiO}_{4}\right)_{6}\right)$ after the refinement and that the results are believable and publishable. Meanwhile, we also refined the concentration of these samples while obtaining the high-quality XRD data. According to these refinement results, the calculated formula are $\mathrm{Ca}_{2.87(2)} \mathrm{La}_{7.13(2)}\left(\mathrm{SiO}_{4}\right)_{6} \mathrm{O}_{2}, \mathrm{Ca}_{4.47(2)} \mathrm{La}_{5.53(2)}\left(\mathrm{SiO}_{4}\right)_{3.53(2)^{-}}$ $\left(\mathrm{PO}_{4}\right)_{2.47(2)} \mathrm{O}_{2}, \quad \mathrm{Ca}_{5.52(2)} \mathrm{La}_{3.48(2)}\left(\mathrm{SiO}_{4}\right)_{1.48(2)}\left(\mathrm{PO}_{4}\right)_{4.52(2)} \mathrm{O}_{2} \quad$ and $\mathrm{Ca}_{8.28(2)} \mathrm{La}_{1.72(2)}\left(\mathrm{PO}_{4}\right)_{6} \mathrm{O}_{2}$, demonstrating that the refined concentrations are highly consistent with the suggested formula and that the coordination environment variation is mainly caused by the replacement of a $\mathrm{Ca}^{2+}$ with a $\mathrm{La}^{3+}$ ion. Moreover, according to the XRD data and the Rietveld refinement, no additive superstructure peaks were detected, this feature proves that the $\mathrm{Ca}^{2+}$ ions and the $\mathrm{La}^{3+}$ ions were randomly mixed at the atomic level. ${ }^{24}$ In addition, the unit lattice parameters and the unit cell volumes of the as-prepared phosphors are given in Fig. 4. The high linear fitting coefficients (0.99334-0.99796) proved the crystal structure evolution of this continuous solid solution. The lattice parameters and unit cell volumes show linear decreases and are proportional to the value of $x$, which is attributed to the substitution of the large $\mathrm{La}^{3+}$ ions by small $\mathrm{Ca}^{2+}$ ions, suggesting that the coordination environment of the cations become more

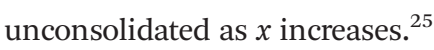

As shown in Fig. 5a-d, the linear change in the crystal structure of these solid solution phosphors was further verified by HRTEM and fast Fourier transform (FFT) images. Both the HRTEM and FFT images illustrate that no significant structural defects appeared in the selected areas of these singlephase samples and that good crystallinity was obtained. Moreover, the lattice fringe measurements with the $d$ spacings of $0.315 \mathrm{~nm}, 0.837 \mathrm{~nm}, 0.354 \mathrm{~nm}$, and $0.353 \mathrm{~nm}$ could be assigned to the planes (210), (010), (021) and (021) for 

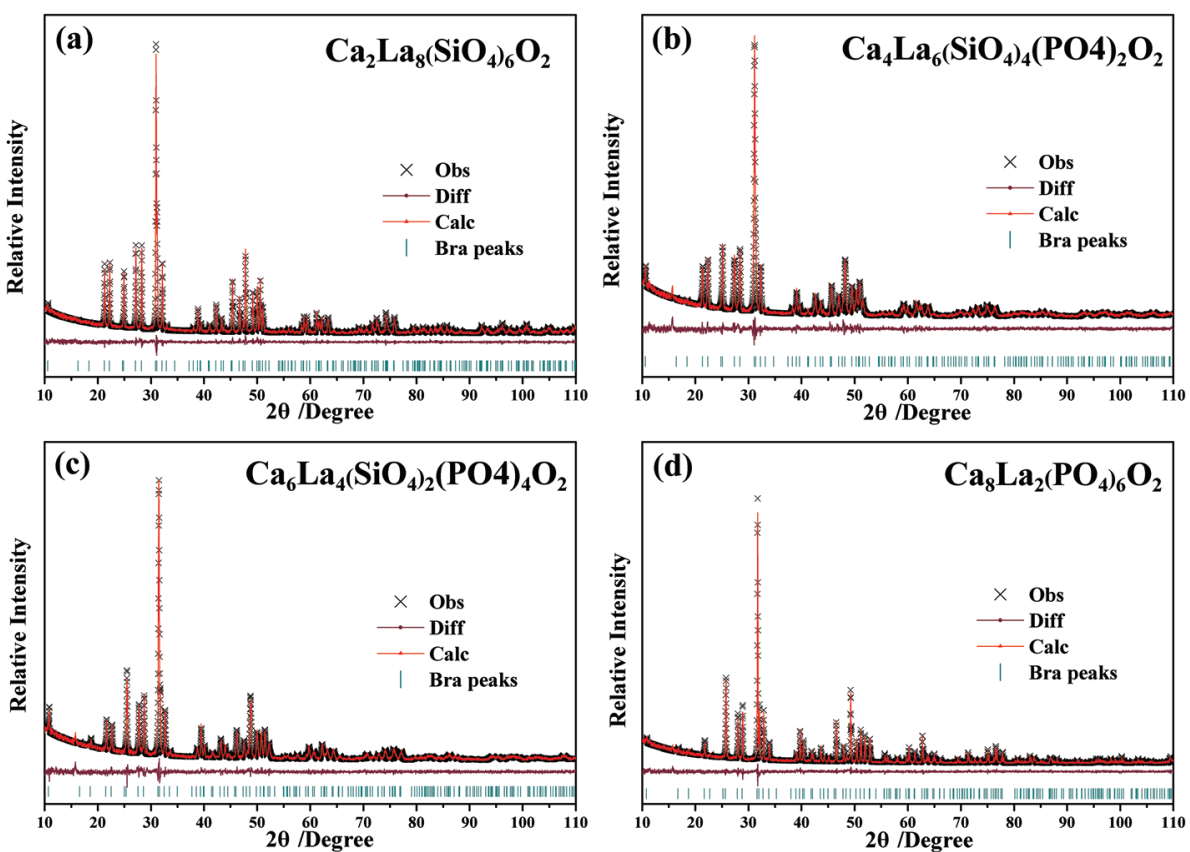

Fig. 3 (a-d) Powder XRD patterns $(x)$ of the $\mathrm{Ca}_{2+x} \mathrm{La}_{8-x}\left(\mathrm{SiO}_{4}\right)_{6-x}\left(\mathrm{PO}_{4}\right)_{x} \mathrm{O}_{2}: 0.02 \mathrm{Eu}^{2+}(x=0,2,4,6)$ samples with the corresponding Rietveld refinement (red) and residuals (gray).

Table 2 The main refinement parameters of $\mathrm{Ca}_{2+x} \mathrm{La}_{8-x}\left(\mathrm{SiO}_{4}\right)_{6-x^{-}}$ $\left(\mathrm{PO}_{4}\right)_{x} \mathrm{O}_{2}(x=0,2,4,6)$

\begin{tabular}{lllll}
\hline Compound & $x=0$ & $x=2$ & $x=4$ & $x=6$ \\
\hline Sp.Gr. & $P 6_{3} / m$ & $P 6_{3} / m$ & $P 6_{3} / m$ & $P 6_{3} / m$ \\
$a, \AA$ & $9.6559(1)$ & $9.5948(6)$ & $9.5325(4)$ & $9.4606(2)$ \\
$b, \AA$ & $9.6559(1)$ & $9.5948(6)$ & $9.5325(4)$ & $9.4606(2)$ \\
$c, \AA$ & $7.1529(1)$ & $7.0882(5)$ & $7.0206(4)$ & $6.9356(1)$ \\
$\alpha, \circ$ & 90 & 90 & 90 & 90 \\
$\beta, \circ$ & 90 & 90 & 90 & 90 \\
$\gamma, \circ$ & 120 & 120 & 120 & 120 \\
$V, \AA^{3}$ & $577.56(2)$ & $565.12(8)$ & $552.49(6)$ & $537.59(2)$ \\
$2 \theta$-Interval, & $10-110$ & $10-110$ & $10-110$ & $10-110$ \\
$R_{\text {wp }}, \%$ & 10.038 & 11.012 & 10.135 & 10.065 \\
$R_{\text {exp }}, \%$ & 1.311 & 1.299 & 1.287 & 1.325 \\
$R_{\mathrm{B}}, \%$ & 2.268 & 2.168 & 1.792 & 2.777 \\
& & & &
\end{tabular}

$\mathrm{Ca}_{2+x} \mathrm{La}_{8-x}\left(\mathrm{SiO}_{4}\right)_{6-x}\left(\mathrm{PO}_{4}\right)_{x} \mathrm{O}_{2}: 0.02 \mathrm{Eu}^{2+} \quad(x=0,2,4,6)$. The measured $d$ spacing in different orientations could be transformed into the same $d$ spacing value of (021) according to the classic Bragg equation. ${ }^{24}$ Therefore, the normalized $d$ spacings of $(021)$ were calculated to be $0.358 \mathrm{~nm}, 0.356 \mathrm{~nm}, 0.354 \mathrm{~nm}$ and $0.353 \mathrm{~nm}$. Consequently, the decrease of the $d$ spacings is well consistent with the refinement results, indicating the existence of structural evolution in the series of solid solutions.

The effective ionic radii of the $\mathrm{Ca}^{2+}$ ions are $1.18(\mathrm{CN}=9)$ and $1.06 \AA(\mathrm{CN}=7)$ and the effective ionic radii of the $\mathrm{La}^{3+}$ ions are $1.21(\mathrm{CN}=9)$ and $1.10 \AA(\mathrm{CN}=7)$. Theoretically, considering the similar ionic radius and valence, the $\mathrm{Eu}^{2+}$ ion $\left(R_{\mathrm{CN}=9}=1.3, R_{\mathrm{CN}=7}=1.2\right)$ is expected to substitute the $\mathrm{La}^{3+}$ and $\mathrm{Ca}^{2+}$ sites in the $\mathrm{Ca}_{2+x} \mathrm{La}_{8-x}\left(\mathrm{SiO}_{4}\right)_{6-x}\left(\mathrm{PO}_{4}\right)_{x} \mathrm{O}_{2} \quad(x=0,2,4,6)$ crystal structure. $^{26}$ Therefore, four kinds of emitting blocks will be included in the host: $\mathrm{Ca}(\mathrm{I}), \mathrm{Ca}(\mathrm{II}), \mathrm{La}(\mathrm{I})$ and $\mathrm{La}(\mathrm{II})$. The occupation rates of $\mathrm{Ca}(\mathrm{I}), \mathrm{Ca}(\mathrm{II}), \mathrm{La}(\mathrm{I})$, and $\mathrm{La}(\mathrm{II})$, reflecting the distribution of $\mathrm{Ca}^{2+}$ ions and $\mathrm{La}^{3+}$ ions in the two cationic sites, have been refined and displayed in Table 3. When the content of $\mathrm{Ca}^{2+}$ ions increases, the occupation rate of $\mathrm{La}(\mathrm{II})$ is decreased faster than that of $\mathrm{La}(\mathrm{I})$ and the $\mathrm{M}$ (II) site is totally occupied by $\mathrm{Ca}^{2+}$ ions while the chemical formula is $\mathrm{Ca}_{8} \mathrm{La}_{2}\left(\mathrm{PO}_{4}\right)_{6} \mathrm{O}_{2}(x=6)$, which shows similar results to the previous studies. ${ }^{16,26}$ The phenomenon can be explained as follows: the $\mathrm{Eu}^{2+}$ ion located at the M(II) site that is connected with a free oxygen ion, results in a very short $\mathrm{Eu}-\mathrm{O}$ distance due to the small sum of the electrostatic bond strength of the cations toward the free oxygen ion. Thus, it must be very unfavorable for the $(6 \mathrm{~h})$ sites to be occupied by a cation with a large radius in these compounds. ${ }^{27}$

\subsection{Photoluminescence characteristics}

The PLE spectra (monitored in the range of $460 \mathrm{~nm}-508 \mathrm{~nm}$ ) and the PL spectra (under $365 \mathrm{~nm}$ excitation) of the $\mathrm{Ca}_{2+x} \mathrm{La}_{8-x}\left(\mathrm{SiO}_{4}\right)_{6-x}\left(\mathrm{PO}_{4}\right)_{x} \mathrm{O}_{2}: 0.02 \mathrm{Eu}^{2+}(x=0,2,4,6)$ phosphors at room temperature are displayed in Fig. $6 \mathrm{a}$ and $\mathrm{b}$, respectively. The PLE spectra depict a series of broad excitation bands between $250 \mathrm{~nm}$ and $450 \mathrm{~nm}$, which are attributed to the $4 \mathrm{f}^{7}$ $\rightarrow 4 \mathrm{f}^{6} 5 \mathrm{~d}^{1}$ transition of the $\mathrm{Eu}^{2+}$ ion, ${ }^{28}$ and the emission spectra show a series of broad emission bands from $400 \mathrm{~nm}$ to $650 \mathrm{~nm}$, which are attributed to the $5 \mathrm{~d} \rightarrow 4 \mathrm{f}$ transition of the $\mathrm{Eu}^{2+}$ ion. As shown in Fig. 6b, a strong asymmetric broad band with a maximum wavelength peak at $508 \mathrm{~nm}$ was detected in the PL spectrum of $\mathrm{Ca}_{2} \mathrm{La}_{8}\left(\mathrm{SiO}_{4}\right)_{6} \mathrm{O}_{2}: 0.02 \mathrm{Eu}^{2+}$, which was 


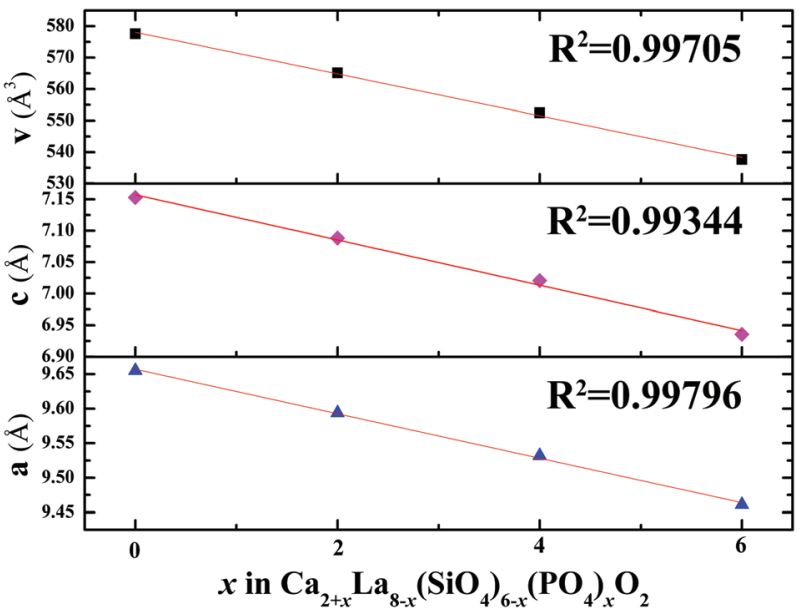

Fig. 4 The refined unit cell parameters $(a, c)$ and cell volume (v) of $\mathrm{Ca}_{2+x} \mathrm{La}_{8-x}\left(\mathrm{SiO}_{4}\right)_{6-x}\left(\mathrm{PO}_{4}\right)_{x} \mathrm{O}_{2}: 0.02 \mathrm{Eu}^{2+}(x=0,2,4,6)$.
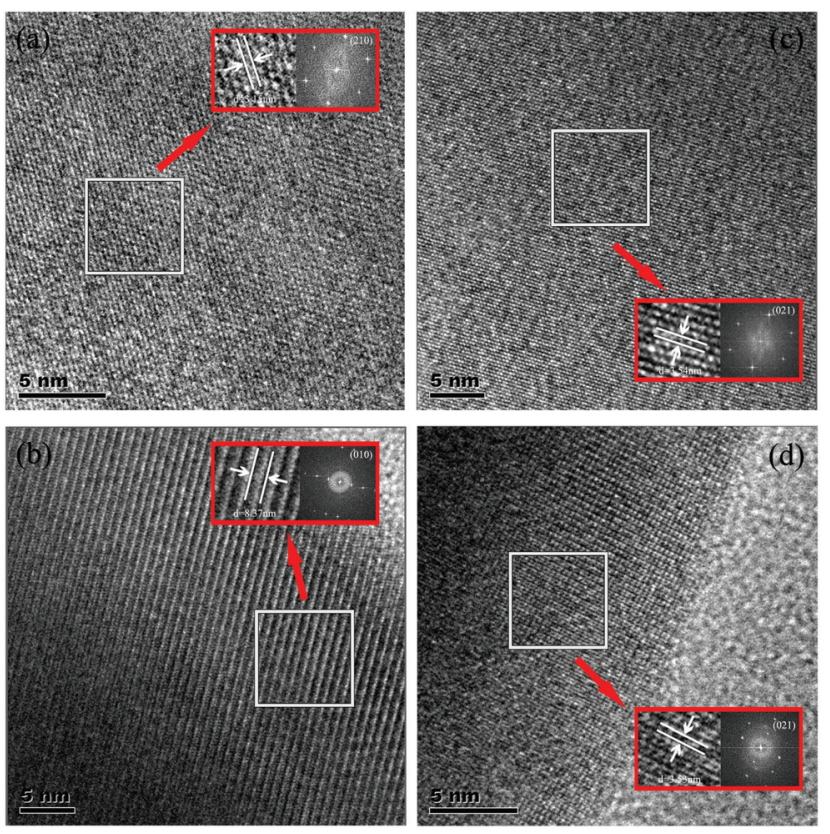

Fig. 5 HRTEM and FFT images for $\mathrm{Ca}_{2+x} \mathrm{La}_{8-x}\left(\mathrm{SiO}_{4}\right)_{6-x^{-}}$ $\left(\mathrm{PO}_{4}\right)_{x} \mathrm{O}_{2}: 0.02 \mathrm{Eu}^{2+}$ with different $x$ values, $x=0$ (a), $x=2$ (b), $x=4$ (c) and $x=6(d)$.

Table 3 Atomic occupation rates in $\mathrm{Ca}_{2+x} \mathrm{La}_{8-x}\left(\mathrm{SiO}_{4}\right)_{6-x}\left(\mathrm{PO}_{4}\right)_{x} \mathrm{O}_{2}$ with different $x$ values

\begin{tabular}{lllll}
\hline Sites & $x=0$ & $x=2$ & $x=4$ & $x=6$ \\
\hline Ca1 & $0.12(2)$ & $0.20(2)$ & $0.43(1)$ & $0.714(7)$ \\
La1 & $0.88(2)$ & $0.80(2)$ & $0.57(1)$ & $0.286(7)$ \\
Ca2 & $0.53(1)$ & $0.81(1)$ & $0.983(7)$ & $1.000(6)$ \\
La2 & $0.47(1)$ & $0.19(1)$ & $0.017(7)$ & $0.000(6)$
\end{tabular}

chosen as the representative of the solid solution phosphors. The asymmetric emission band can be decomposed into two Gaussian component peaks at $504 \mathrm{~nm}$ (I1) and $542 \mathrm{~nm}$ (I2) demonstrating the existence of two types of emitting centers in $\mathrm{Ca}_{2} \mathrm{La}_{8}\left(\mathrm{SiO}_{4}\right)_{6} \mathrm{O}_{2}: 0.02 \mathrm{Eu}^{2+}$.

Fig. $6 \mathrm{c}$ and d display the low temperature (8k) PLE and PL spectra of $\mathrm{Ca}_{2} \mathrm{La}_{8}\left(\mathrm{SiO}_{4}\right)_{6} \mathrm{O}_{2}: 0.02 \mathrm{Eu}^{2+}$ and $\mathrm{Ca}_{8} \mathrm{La}_{2}\left(\mathrm{PO}_{4}\right)_{6}{ }^{-}$ $\mathrm{O}_{2}: 0.02 \mathrm{Eu}^{2+}$. The PL spectra of $\mathrm{Ca}_{2} \mathrm{La}_{8}\left(\mathrm{SiO}_{4}\right)_{6} \mathrm{O}_{2}: 0.02 \mathrm{Eu}^{2+}$ can be separated into two components with peaks at $526 \mathrm{~nm}$ and $576 \mathrm{~nm}$, and the PL spectra of $\mathrm{Ca}_{8} \mathrm{La}_{2}\left(\mathrm{PO}_{4}\right)_{6} \mathrm{O}_{2}: 0.02 \mathrm{Eu}^{2+}$ obviously contains two components with peaks at $460 \mathrm{~nm}$ and $625 \mathrm{~nm}$. The results further demonstrate that there are two kinds of cation sites included in the series of apatite phosphors which could be occupied by the $\mathrm{Eu}^{2+}$ ion.

Actually, considering the valence state and the previous results, ${ }^{16,29}$ the blue emission band observed in the PL spectrum of $\mathrm{Ca}_{2} \mathrm{La}_{8}\left(\mathrm{PO}_{4}\right)_{6} \mathrm{O}_{2}: 0.02 \mathrm{Eu}^{2+}$ is attributed to the substitution of a $\mathrm{Ca}^{2+}$ ion by a $\mathrm{Eu}^{2+}$ ion. According to the report by Van Uitert, to further demonstrate the relationship between emission peaks and emission centers, the possible crystallographic site may be investigated theoretically by the following equation: ${ }^{30}$

$$
E\left(\mathrm{~cm}^{-1}\right)=Q^{*}\left[1-\left(\frac{V}{4}\right)^{1 / V} \times 10^{-\left(n E_{\mathrm{a}} r\right) / 80}\right],
$$

where $E$ represents the energy position of the d-band edge for the rare-earth ion $\left(\mathrm{cm}^{-1}\right), Q^{*}$ is the energy position for the lower d-band edge for the free ion $\left(34000 \mathrm{~cm}^{-1}\right.$ for $\left.\mathrm{Eu}^{2+}\right), V$ is the valence of the activator $\left(\mathrm{Eu}^{2+}\right)$ ion $(V=2), n$ is the number of anions in the immediate shell around the $\mathrm{Eu}^{2+}$ ion, $r$ is the radius of the host cation replaced by the $\mathrm{Eu}^{2+}$ ion (in $\AA$ ), and $E_{\mathrm{a}}$ is the electron affinity of the atoms that form anions (in eV) depending on the anion complex type. Here, $E_{\mathrm{a}}$ was approximately determined as 1.60 for the $\left[\mathrm{SiO}_{4}\right]^{4-}$ in the oxide host ${ }^{31}$ and the $r$ values of $\mathrm{Ca}(\mathrm{I})$ and $\mathrm{Ca}(\mathrm{II})$ were calculated to be 118 pm and $106 \mathrm{pm}$, respectively. Consequently, the $E_{\text {calcd }}$ values of $\mathrm{Ca}(\mathrm{I})$ and $\mathrm{Ca}(\mathrm{II})$ were calculated to be $19693 \mathrm{~cm}^{-1}$ and $18546 \mathrm{~cm}^{-1}$, respectively. The results indicated that the emission band centered at $504 \mathrm{~nm}$ was attributed to a $\mathrm{Eu}^{2+}$ ion occupying the $\mathrm{Ca}(\mathrm{I})$ site with $C_{3}$ symmetry and nine-coordination and that the emission band peaked at $542 \mathrm{~nm}$ was attributed to a $\mathrm{Eu}^{2+}$ ion occupying the $\mathrm{Ca}$ (II) site with $C_{\mathrm{S}}$ symmetry and seven-coordination.

The emission wavelengths of the $\mathrm{Ca}_{2+x} \mathrm{La}_{8-x}\left(\mathrm{SiO}_{4}\right)_{6-x^{-}}$ $\left(\mathrm{PO}_{4}\right)_{x} \mathrm{O}_{2}: 0.02 \mathrm{Eu}^{2+}(x=0,2,4,6)$ PL spectra show a wide blue shift from $508 \mathrm{~nm}$ to $460 \mathrm{~nm}$ with the increase of the $x$ value which is dependent on the crystal field strength variation. The structural model of the cation substitution around the $\mathrm{Eu}^{2+}$ ion sites is depicted in Fig. 7. In this regard, the crystal field splitting of the $\mathrm{Eu}^{2+}$ ions can be determined as obeying: ${ }^{17,32,33}$

$$
D_{\mathrm{q}}=\frac{z e^{2} r^{4}}{6 R^{5}}
$$

where $D_{\mathrm{q}}$ is a measure of energy level separation, $R$ represents the distance from the central ion to its ligands, $z$ stands for the charge or valence of the anion, $r$ is the radius of the $d$ wave 

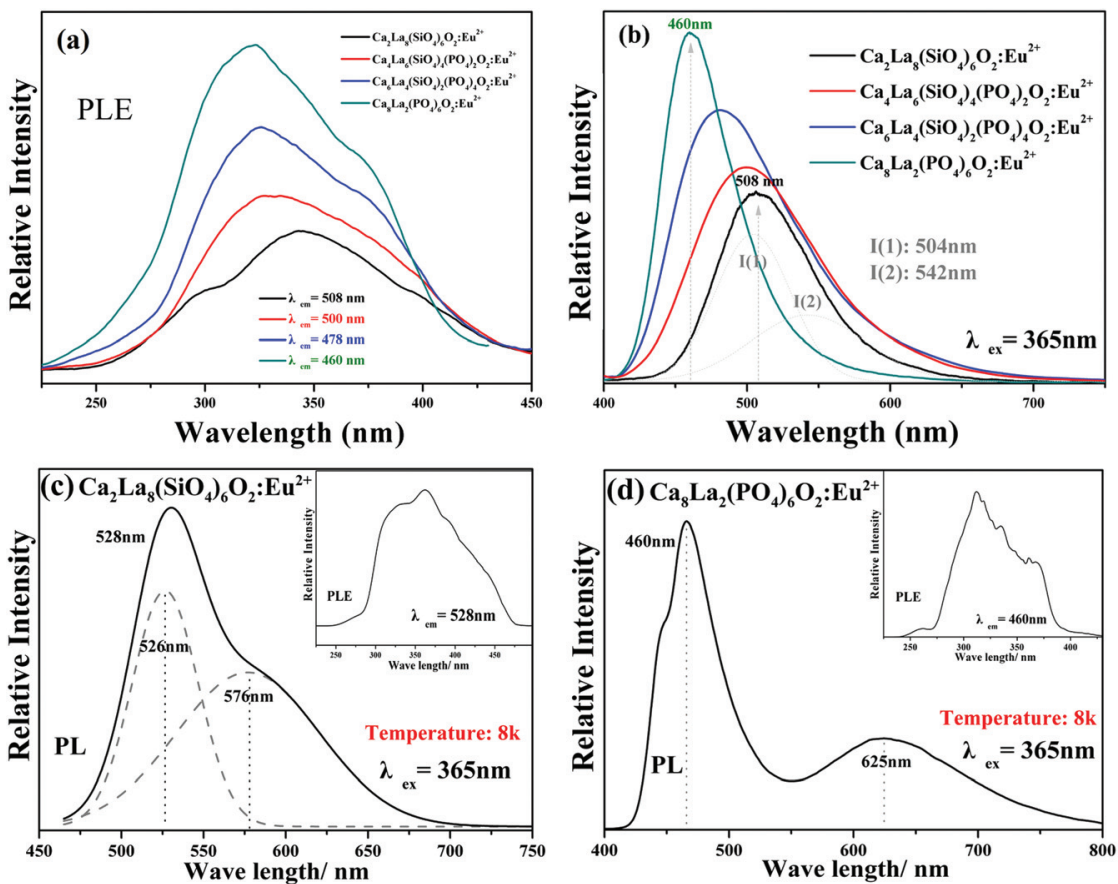

Fig. 6 (a) The PLE monitored in the range of $460 \mathrm{~nm}-508 \mathrm{~nm}$ and (b) the PL spectra under $365 \mathrm{~nm}$ excitation of $\mathrm{Ca}_{2+x} \mathrm{La}_{8-x}\left(\mathrm{SiO}_{4}\right)_{6-x}\left(\mathrm{PO}_{4}\right)_{x} \mathrm{O}_{2}: 0.02 \mathrm{Eu}^{2+}(x=0,2,4,6)$ at room temperature. (c) The PL and PLE spectra at low temperature $(8 \mathrm{k})$ of $\mathrm{Ca}_{2} \mathrm{La}_{8}\left(\mathrm{SiO}_{4}\right)_{6} \mathrm{O}_{2}: 0.02 \mathrm{Eu}^{2+}$ and (d) the PL and PLE spectra at low temperature (8k) of $\mathrm{Ca}_{8} \mathrm{La}_{2}\left(\mathrm{PO}_{4}\right)_{6} \mathrm{O}_{2}: 0.02 \mathrm{Eu}^{2+}$.

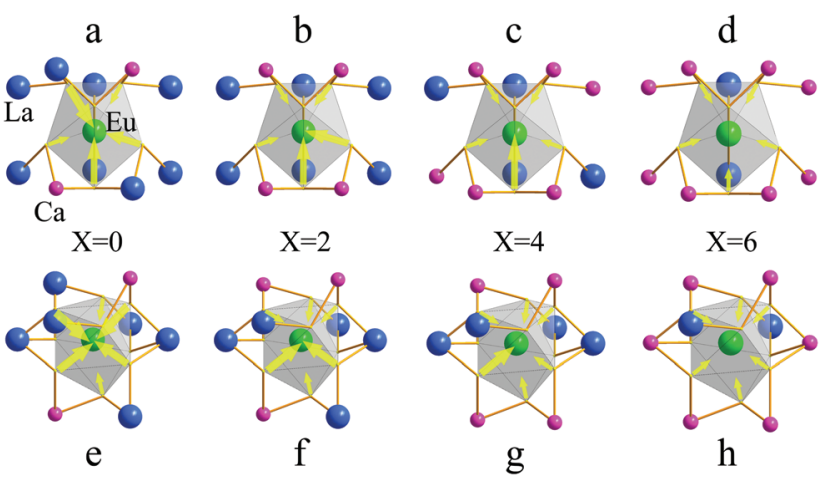

Fig. 7 Structural model for explaining the photoluminescence evolution observed in the $\mathrm{Ca}_{2+x} \mathrm{La}_{8-x}\left(\mathrm{SiO}_{4}\right)_{6-x}\left(\mathrm{PO}_{4}\right)_{x} \mathrm{O}_{2}: 0.02 \mathrm{Eu}^{2+}(x=0,2,4,6)$ phosphors: $(a-d)$ represent $\mathrm{Eu}^{2+}$ located in the $M(1)$ site, $(e-h)$ represent $\mathrm{Eu}^{2+}$ located in the $\mathrm{M}(\mathrm{II})$ site.

function, and $e$ is the charge of an electron. For the $\mathrm{d}_{(\mathrm{Eu}-\mathrm{O})^{-}}$ orbital, if $z, e$ and $r$ are equal, then $D_{\mathrm{q}}$ is only a function of $1 / R^{5}$. When the large $\mathrm{La}^{3+}$ ion is substituted by the small $\mathrm{Ca}^{2+}$ ion, the distance between $\mathrm{Eu}^{2+}$ and $\mathrm{O}^{2+}$ becomes longer and the magnitude of the crystal field strength decreases. ${ }^{34,35}$ Thus, the crystal field splitting of the $\mathrm{Eu}^{2+}$ ion is reasonably decreased and this results in a gradual increase of the lowest $5 \mathrm{~d}$ state. ${ }^{36}$ As a consequence, the emission wavelength shows a blue shift among the as-prepared phosphors and a color variation from green to blue.
In addition, as shown in Table 4, the stokes shifts were estimated to be $6135 \mathrm{~cm}^{-1}-5985 \mathrm{~cm}^{-1}$ and the full width at halfmaximum (FWHMs) of the PLE spectra decrease from $142 \mathrm{~nm}$ to $113 \mathrm{~nm}$ with the increase in $x$. The crystal-field splitting of the $\mathrm{Eu}^{2+}$ ions was estimated to be $22230 \mathrm{~cm}^{-1}-18190 \mathrm{~cm}^{-1}$, which is calculated by the gap between the first and the last component peaks of the PLE spectra. All the computations further demonstrate the decrease of the crystal field splitting. ${ }^{37}$

Furthermore, Fig. 8 presents the room temperature decay curves of the $\mathrm{Eu}^{2+}$ ion luminescence in the $\mathrm{Ca}_{2+x} \mathrm{La}_{8-x}\left(\mathrm{SiO}_{4}\right)_{6-x}\left(\mathrm{PO}_{4}\right)_{x} \mathrm{O}_{2}: 0.02 \mathrm{Eu}^{2+}(x=0,2,4,6)$ series. All of the decay curves can be well fitted with a second order exponential equation:

$$
I(t)=A_{1} \exp \left(-t / \tau_{1}\right)+A_{2} \exp \left(-t / \tau_{2}\right)
$$

where $I(t)$ is the luminescence intensity, $A_{1}$ and $A_{2}$ represent constants, $\tau$ is the time, and $\tau_{1}$ and $\tau_{2}$ stand for rapid and

Table 4 Excitation and emission bands, stokes shift, and the crystal field splitting of the $\mathrm{Ca}_{2+x} \mathrm{La}_{8-x}\left(\mathrm{SiO}_{4}\right)_{6-x}\left(\mathrm{PO}_{4}\right)_{x} \mathrm{O}_{2}: 0.02 \mathrm{Eu}^{2+}(x=0,2,4,6)$ phosphors

\begin{tabular}{llllll}
\hline$x$ & $\begin{array}{l}\lambda_{\text {ex }} \text { range } \\
\text { Values } \\
(\mathrm{nm})\end{array}$ & $\begin{array}{l}\text { FWHM of } \\
\lambda_{\text {ex }}(\mathrm{nm})\end{array}$ & $\begin{array}{l}\lambda_{\text {em }} \\
(\mathrm{nm})\end{array}$ & $\begin{array}{l}\text { Stokes } \\
\text { shift }\left(\mathrm{cm}^{-1}\right)\end{array}$ & $\begin{array}{l}\text { Crystal field } \\
\text { splitting }\left(\mathrm{cm}^{-1}\right)\end{array}$ \\
\hline 0 & $250-450$ & 142 & 508 & 6135 & 22230 \\
2 & $250-450$ & 127 & 500 & 6082 & 20833 \\
4 & $250-450$ & 118 & 478 & 6039 & 19231 \\
6 & $250-400$ & 113 & 460 & 5985 & 18190
\end{tabular}




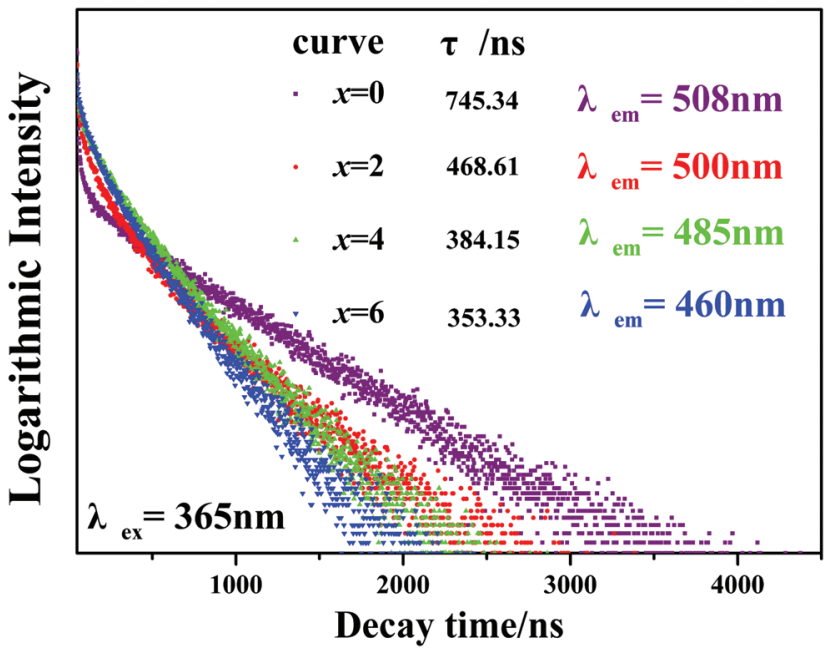

Fig. 8 Room temperature decay curves of the $\mathrm{Ca}_{2+x} \mathrm{La}_{8-x}\left(\mathrm{SiO}_{4}\right)_{6-x^{-}}$ $\left(\mathrm{PO}_{4}\right)_{x} \mathrm{O}_{2}: 0.02 \mathrm{Eu}^{2+}(x=0,2,4,6)$ phosphors.

slow lifetimes for exponential components, respectively. Moreover, the effective lifetime constant $\left(\tau^{*}\right)$ can be calculated as:

$$
\tau *=\left(A_{1} \tau_{1}^{2}+A_{2} \tau_{2}^{2}\right) /\left(A_{1} \tau_{1}+A_{2} \tau_{2}\right)
$$

The effective decay times were calculated to be 745.34 , $468.61,384.15$ and 353.33 ns with $x=0,2,4$ and 6, respectively. One can see that the decay times decrease with the increasing $\mathrm{Ca}^{2+}$ ion content. Due to the phase structures becoming more unconsolidated compared to the original $\mathrm{Ca}_{2} \mathrm{La}_{8}\left(\mathrm{SiO}_{4}\right)_{4}: 0.02 \mathrm{Eu}^{2+}$ phase, the increasing possibility of energy transfer among the $\mathrm{Eu}^{2+}$ ions increases the possible non-radiative transition and leads to the decreasing lifetime values. $^{32,38}$ Also the two decay components $\left(\tau_{1}\right.$ and $\left.\tau_{2}\right)$ proved that the $\mathrm{Eu}^{2+}$ occupied two different $\mathrm{Ca}^{2+}$ sites. ${ }^{13}$

The temperature dependence experiment proved that the thermal stability is consistent with the crystal structure evolution in the as-prepared series phosphors, and the peak emission intensity that normalized to $25{ }^{\circ} \mathrm{C}$ values was depicted in Fig. 9. As shown in Fig. 9, the emission intensity of all the samples decreases with the increase in temperature. Additionally, the thermal stability gradually decreases with the increasing $x$ values, this phenomenon can be explained by the neighboring-cation effect. ${ }^{39,40}$ The replacement of large $\mathrm{La}^{3+}$ ions by small $\mathrm{Ca}^{2+}$ ions makes the distances between the $\mathrm{Eu}^{2+}$ activator ion and the neighboring cations become smaller, as demonstrated by the refined cell parameters and cell volume, resulting in a larger coulombic force following the inversesquare law ${ }^{41,42}$ and the decrease of the thermal quenching barrier height. Thus, the thermal stability becomes lower when the replacement occurs.

Luminescence efficiency is an important technological parameter for the application of phosphors. The internal quantum efficiency (QE) of the $\mathrm{Ca}_{2+x} \mathrm{La}_{8-x}\left(\mathrm{SiO}_{4}\right)_{6-x}\left(\mathrm{PO}_{4}\right)_{x^{-}}$

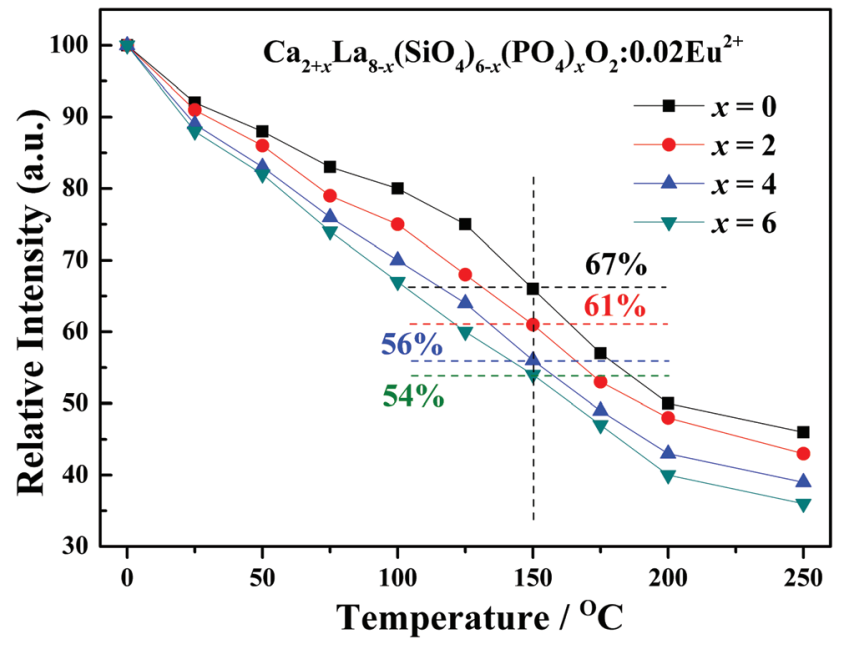

Fig. 9 The peak emission intensity of temperature dependence that normalized to $25^{\circ} \mathrm{C}$ values.

$\mathrm{O}_{2}: 0.02 \mathrm{Eu}^{2+}(x=0,2,4,6)$ phosphors was measured and calculated following: ${ }^{12}$

$$
\eta_{\mathrm{QE}}=\frac{\int L_{\mathrm{S}}}{\int E_{\mathrm{R}}+\int E_{\mathrm{S}}}
$$

where $L_{\mathrm{S}}$ is the luminescence emission spectrum of the sample, $E_{\mathrm{R}}$ represents the spectrum of the excitation light from the empty integrated sphere (without the sample), and $E_{\mathrm{S}}$ stands for the excitation spectrum for exciting the sample. As a result, under $365 \mathrm{~nm}$ excitation, the internal $\mathrm{QE}$ of the $\mathrm{Ca}_{2+x} \mathrm{La}_{8-x}\left(\mathrm{SiO}_{4}\right)_{6-x}\left(\mathrm{PO}_{4}\right)_{x} \mathrm{O}_{2}: 0.02 \mathrm{Eu}^{2+}(x=0,2,4,6)$ phosphors was estimated to be about $45.44 \%, 46.39 \%, 44.12 \%$ and

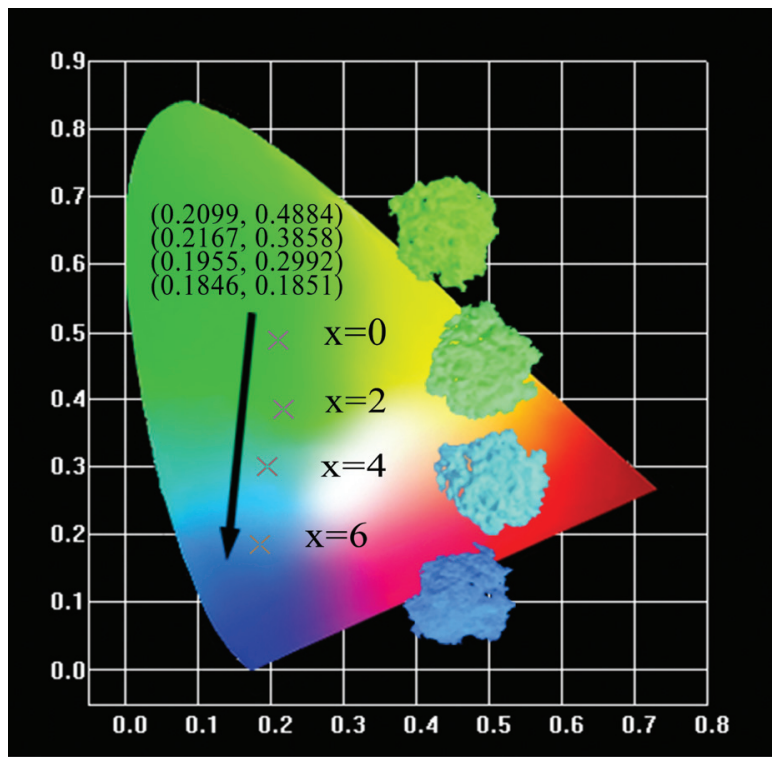

Fig. 10 The $\mathrm{CIE}$ coordinates and the digital photos of the $\mathrm{Ca}_{2+x} \mathrm{La}_{8-x}\left(\mathrm{SiO}_{4}\right)_{6-x}\left(\mathrm{PO}_{4}\right)_{x} \mathrm{O}_{2}: 0.02 \mathrm{Eu}^{2+}(x=0,2,4,6)$ phosphors. 
$46.56 \%$ for $x=0,2,4$, and 6, respectively. The QE of the asprepared phosphors can be further optimized by improving the preparation conditions because the QE depends closely on the prepared conditions, crystalline defects, particle sizes and the morphology of the phosphor. ${ }^{25,39}$

The CIE coordinates and the digital photos of the $\mathrm{Ca}_{2+x} \mathrm{La}_{8-x}\left(\mathrm{SiO}_{4}\right)_{6-x}\left(\mathrm{PO}_{4}\right)_{x} \mathrm{O}_{2}: 0.02 \mathrm{Eu}^{2+}(x=0,2,4,6)$ phosphors under $365 \mathrm{~nm}$ excitation are displayed in Fig. 10. The calculated CIE coordinates are $(0.2099,0.4884)$ for $x=0,(0.2167$, $0.3585)$ for $x=2,(0.1955,0.2992)$ for $x=4$ and $(0.1846,0.1851)$ for $x=6$. Obviously, both the digital photos and the coordinates demonstrate that the emitted color of the solid solution phosphors $\mathrm{Ca}_{2+x} \mathrm{La}_{8-x}\left(\mathrm{SiO}_{4}\right)_{6-x}\left(\mathrm{PO}_{4}\right)_{x} \mathrm{O}_{2}: 0.02 \mathrm{Eu}^{2+}(x=0,2,4,6)$ can be adjusted in the wide range from green to blue by changing the ratio of $\mathrm{Ca} / \mathrm{La}$.

\section{Conclusions}

In summary, a series of continuous solid solution phosphors $\mathrm{Ca}_{2+x} \mathrm{La}_{8-x}\left(\mathrm{SiO}_{4}\right)_{6-x}\left(\mathrm{PO}_{4}\right)_{x} \mathrm{O}_{2}: 0.02 \mathrm{Eu}^{2+}(x=0,2,4,6)$ were successfully synthesized by a solid-state reaction method. The phase purity was examined by XRD, XPS and XRF, the crystal structure information was identified by both Rietveld refinement and HRTEM. The refined concentration, cell parameters and occupation rate matched well with the suggested formula and the variation tendency of $\mathrm{Ca} / \mathrm{La}$ demonstrating that $\mathrm{Eu}^{2+}$ activated $\mathrm{Ca}_{2} \mathrm{La}_{8}\left(\mathrm{SiO}_{4}\right)_{6} \mathrm{O}_{2}$ and $\mathrm{Ca}_{8} \mathrm{La}_{2}\left(\mathrm{PO}_{4}\right)_{6} \mathrm{O}_{2}$ to form continuous solid solution phosphors. Different spectroscopic behavior properties based on structural variations were verified among the series of phosphors. The PL spectra at room temperature and low temperature (8k) were well separated into two component peaks, demonstrating that there are two kinds of $\mathrm{Eu}^{2+}$ ion sites included in these apatite phosphors. Furthermore, the short wavelength emission peak is from the $\mathrm{Eu}^{2+}$ ion located at the $4 \mathrm{f}$ site with nine coordination and the long wavelength emission peak is ascribed to the $\mathrm{Eu}^{2+}$ ion occupying the $6 \mathrm{~h}$ site with seven coordination. Under $365 \mathrm{~nm}$ excitation, the series of phosphors show a strong blue shift from $508 \mathrm{~nm}$ to $460 \mathrm{~nm}$. It can be explained by the fact that the substitution of the large $\mathrm{La}^{3+}$ ions by small $\mathrm{Ca}^{2+}$ ions induced a decreased crystal field splitting of the $\mathrm{Eu}^{2+}$ ions, which led to the emission energy from the $5 \mathrm{~d}$ excited state to the $4 \mathrm{f}$ ground state increasing. Consequently, the emitted color of the series of phosphors could be tuned from green to blue by adjusting the ratio of $\mathrm{Ca} / \mathrm{La}$.

\section{Acknowledgements}

This work was sponsored by National Natural Science Foundation of China (Grant No. 51472223), the Program for New Century Excellent Talents in University of Ministry of Education of China (Grant No. NCET-12-0951) and the Fundamental Research Funds for the Central Universities (Grant No. 2652015020).

\section{References}

1 W. R. Liu, C. H. Huang, C. W. Yeh, J. C. Tsai, Y. C. Chiu, Y. T. Yeh and R. S. Liu, Inorg. Chem., 2012, 51, 9636.

2 H. Wu, X. M. Zhang, C. F. Guo, J. Xu, M. M. Wu and Q. Su, IEEE Photonics Technol. Lett., 2015, 17, 1160-1162.

3 X. J. Zhang, L. Huang, F. J. Pan, M. M. Wu, J. Wang, Y. Chen and Q. Su, ACS Appl. Mater. Interfaces, 2014, 6, 2709-2717.

4 M. M. Shang, D. L. Geng, D. M. Yang, X. Kang, Y. Zhang and J. Lin, Inorg. Chem., 2013, 52, 3102-3112.

5 Z. G. Xia, Y. Y. Zhang, M. S. Molokeev and V. V. Atuchin, J. Phys. Chem. C, 2013, 117, 20847-20854.

6 J. Chen, Y. G. Liu, M. H. Fang and Z. H. Huang, Inorg. Chem., 2014, 53, 11396-11407.

7 X. J. Zhang, J. Wang, L. Huang, F. J. Pan, Y. Chen, B. F. Lei, M. Y. Peng and M. M. Wu, ACS Appl. Mater. Interfaces, 2015, 7, 10044-10054.

8 J. Chen, Y. G. Liu, H. K. Liu, H. Ding, M. H. Fang and Z. H. Huang, Opt. Mater., 2015, 42, 80-86.

9 M. Zhang, J. Wang, Z. Zhang, Q. Zhang and Q. Su, Appl. Phys. B: Lasers Opt., 2008, 93, 829-835.

10 K. H. Kwon, W. B. Im, H. S. Jang, H. S. Yoo and D. Y. Jeon, Inorg. Chem., 2009, 48, 11525-11532.

11 P. Dorenbos, J. Lumin., 2003, 104, 239-260.

12 J. Chen, Y. G. Liu, L. F. Mei, H. K. Liu, M. H. Fang and Z. H. Huang, Sci. Rep., 2015, 14, 13258.

13 Z. Xia, M. S. Molokeev, W. B. Im, S. Unithrattil and Q. Liu, J. Phys. Chem. C, 2015, 119, 9488-9495.

14 G. Zhu, Y. R. Shi, M. Mikami, Y. Shimomura and Y. H. Wang, Opt. Mater., 2013, 3, 229-236.

15 H. K. Liu, Y. Y. Zhang, L. B. Liao, Q. F. Guo and L. F. Mei, Ceram. Int., 2014, 40, 13709-13713.

16 M. M. Shang, G. G. Li, D. L. Geng, D. M. Yang, X. J. Kang, Y. Zhang, H. Z. Lian and J. Lin, J. Phys. Chem. C, 2012, 116, 10222-10231.

17 N. Guo, H. P. You, C. Z. Ji, R. Z. Ouyang and D. H. Wu, Dalton Trans., 2014, 43, 12373-12379.

18 G. G. Li, Y. Zhang, D. L. Geng, M. M. Shang, C. Peng and J. Lin, ACS Appl. Mater. Interfaces, 2012, 4, 296-305.

19 Y. Zhang, G. G. Li, D. L. Geng, M. M. Shang, C. Peng and J. Lin, Inorg. Chem., 2012, 51, 11655-11664.

20 H. P. Ji, Z. H. Huang, Z. G. Xia, M. S. Molokeev, V. V. Atuchin, M. H. Fang and Y. G. Liu, J. Phys. Chem. C, 2015, 119, 2038-2045.

21 Y. R. Do, K. Y. Ko, S. H. Na and Y. D. Huh, J. Electrochem. Soc., 2006, 153, 142-146.

22 F. M. Ryan, R. W. Warren, R. H. Hopkins and J. Murphy, J. Electrochem. Soc., 1978, 125, 1493-1498.

23 W. Y. Huang, F. Yoshimure, K. Ueda, Y. Shimomura, H. S. Sheu, T. S. Chen, H. F. Greer, W. Z. Zhou, S. F. Hu, R. S. Liu and J. P. Attfield, J. Am. Chem. Soc., 2012, 134, 14108.

24 Z. Xia, Y. Zhang, M. S. Molokeev, V. V. Atuchin and Y. Luo, Sci. Rep., 2013, 3, 3310. 
25 K.-W. Huang, W.-T. Chen, C.-I. Chu, S.-F. Hu, H.-S. Sheu, B.-M. Cheng, J.-M. Chen and R.-S. Liu, Chem. Mater., 2012, 24, 2220-2227.

26 R. E. Ouenzerfia, G. Panczera, C. Goutaudiera, M. T. Cohen-Adada, G. Boulona, M. Trabelsi-Ayedib and N. Kbir-Ariguibc, Opt. Mater., 2001, 16, 301-310.

27 G. Li, D. Geng, M. Shang, Y. Zhang, C. Peng, Z. Cheng and J. Lin, J. Phys. Chem. C, 2011, 115, 21882-21892.

28 G. Blasse, W. L. Wanmaker, J. W. Tervrugt and A. Bril, Philips Res. Rep., 1968, 23, 189-200.

29 B. Lee, S. Lee, H. G. Jeong and K. S. Sohn, ACS Comb. Sci., 2011, 13, 154-158.

30 V. Uitert, J. Lumin., 1984, 29, 1-9.

31 H. P. Ji, Z. H. Huang, Z. G. Xia, M. S. Molokeev, X. X. Jiang, Z. H. Lin and V. V. Atuchin, Dalton Trans., 2015, 44, 76797686.

32 C. Zhao, Z. Xia and S. Yu, J. Mater. Chem. C, 2014, 2, 6032.

33 C.-H. Huang, P.-J. Wu, J.-F. Lee and T.-M. Chen, J. Mater. Chem., 2011, 21, 10489.

34 P. Dorenbos, Phys. Rev. B: Condens. Matter, 2001, 64, 117125.
35 K. A. Denault, J. Brgoch, M. W. Gaultois, A. Mikhailovsky, R. Petry, H. Winkler, S. P. DenBaars and R. Seshadri, Chem. Mater., 2014, 26, 2275-2282.

36 C. H. Huang, Y. C. Chiu, Y. T. Ye, T. S. Chan and T. M. Chen, ACS Appl. Mater. Interfaces, 2012, 4, 66616668.

37 G. P. Dong, X. D. Xiao, L. L. Zhang, Z. J. Ma, X. Bao, M. Y. Peng, Q. Y. Zhang and J. R. Qiu, J. Mater. Chem., 2011, 21, 2194-2203.

38 J. Zhou, Z. Xia, M. Chen, M. S. Molokeev and Q. Liu, Sci. Rep., 2015, 5, 12149.

39 N. Guo, Y. Zheng, Y. Jia, H. Qiao and H. You, J. Phys. Chem. C, 2012, 116, 1329-1334.

40 W. Y. Huang, F. Yoshimure, K. Ueda, Y. Shimomura, H. S. Sheu, T. S. Chen, H. F. Greer, W. Z. Zhou, S. F. Hu, R. S. Liu and J. P. Attfield, J. Am. Chem. Soc., 2012, 134, 14108.

41 D. J. Griffiths, Introduction to Electrodynamics, Prentice Hall, 3rd edn, 1998, ISBN 0-13-805326-X.

42 Z. Y. Wang, Z. G. Xia, M. S. Molokeev, V. V. Atuchin and Q. L. Liu, Dalton Trans., 2014, 43, 16800. 